\title{
Hunting for nature's treasures or learning from nature? The narrative ambivalence of the ecotechnological turn
}

\author{
Sanne van der Hout \& Martin Drenthen
}

\begin{abstract}
Scientists need narrative structures, metaphors and images to explain and legitimize research practices that are usually described in abstract and technical terms. Yet, sometimes they do not take proper account of the complexity and multi-layered character of their narrative self-presentations. This also applies to the narratives of ecotechnology explored in this article: the treasure quest narrative used in the emerging field of metagenomics, and the tutorial narrative proposed by the learningfrom-nature movement biomimicry. Researchers from both fields tend to underestimate the general public's understanding of the inherent ambivalence of the narratives suggested by them; the treasure quest and tutorial narratives build upon larger master-narratives which can be found throughout our culture, for instance in literature, art and film. We will show how these genres reveal the moral ambivalence of both narratives, using two well-known movies as illustrations: Raiders of the Lost Ark (1981) and Disney's The Sorcerer's Apprentice (1940).
\end{abstract}

Keywords: biomimicry, ecotechnology, environmental ethics, metagenomics, narratives, resourcism, self-presentations

\section{Introduction}

Over the past few decades, biological knowledge has grown rapidly. We have discovered that the mechanisms and processes of nature are much more complex, intricate and interwoven than we ever imagined. As "[w]e can see, more clearly than ever before, how nature works her miracles" (Benyus 2002: 6), an increasing number of scientists, designers, and engineers claim that we are entering a new technological era, in which we are 're-inventing' our relationship with nature (Ball 2001; McDonough and Braungart 2002; Benyus 2002). Whereas more traditional technological approaches are based on principles that are different from, and often disturb or interfere with the dynamics of nature (Sloterdijk and Heinrichs 2006), new technological approaches are increasingly inspired by "nature's surprisingly effective design principles" (McDonough and Braungart 2002: 6). This desire to produce technological devices that mimic the natural world as closely as possible reveals an 'ecotechnological turn', meaning that nature's own strategies, developed in the course of the long and winding road of evolution, provide the models for our innovations.

Scientists have found various ways to express this shift towards more 'natural' approaches to nature, making use of different narrative structures, metaphors, and images. With these narrative self-presentations, they seek to express in what ways the new approach to technology can be distinguished from the old, as well as to legitimize their research activities. In this article, we will explore two of these 'narratives of ecotechnology'. Firstly, researchers 
in the emerging field of metagenomics compare the new practice of uncovering the Earth's microbial diversity with a quest for a treasure (for instance Oh et al. 2003: 248; Committee on Metagenomics 2007: 76; Schoenfeld et al. 2010: 20). This narrative is meant to draw attention to the wealth of products yet to be discovered in nature: the ecotechnological turn is presented as a quest for the 'goods' nature has produced in the process of evolution. But there are also more critical voices claiming that the treasure quest narrative does not provide a full picture of what is at stake in ecotechnology. One of them is Janine Benyus, co-founder of the Biomimicry Institute (Montana). If we want to do justice to nature's own creative processes, argues Benyus, we should "view nature as a source of ideas instead of goods" (Biomimicry 3.8). She expresses this alternative view by referring to a different type of narrative, one that sees the emerging ecotechnological practice of 'biomimicry' as a tutorial practice. By referring to nature as our 'mentor', Benyus shows that for her, the ecotechnological turn not only implies that we acknowledge the superiority of the 'goods' produced by nature; it is also connected with "a new way of viewing and valuing nature" (2002: front pages). Once we recognize nature as our mentor, we simultaneously have to recognize ourselves as nature's students, open to the lessons nature has in store for us.

Benyus presents the tutorial relationship as the opposite of the practice of treasure hunting. However, we will show that these two narrative self-presentations are strikingly similar in one respect: ecotechnologists have selected these narratives because of their positive connotations; the use of them is part of a deliberate communication strategy of public "expectation management" (Borup et al. 2006). The treasure quest narrative stresses that although the development of ecotechnology will require full commitment and high investments, these sacrifices will result in a great material reward in the end, in the form of new products beneficial to humans (antibiotics, vitamins, enzymes). The tutorial narrative comes with a promise as well, albeit a rather different one: if we listen carefully to nature's lessons, pay close attention to the ways in which our teacher tackles design challenges, we will ourselves become smarter and better problem solvers as well. Here, the 'prize' is not so much a material, but rather an intellectual reward.

Yet, as we will argue in this article, metagenomicists and biomimicry practitioners tend to underestimate the general public's understanding of the inherent ambivalence of the narratives proposed by them; both the treasure quest and the teacher-student narratives are embedded in larger, more common narratives which can be found throughout our culture, for instance in literature, art, and film. They are embedded in larger 'master-narratives' (Heller 2006) that surface time and again in relation to research and innovation, and tend to structure lay people's symbolic thought (Dupuy 2010). We will show how these genres reveal the ambivalence and complexity of both narratives, using two well-known movies as illustrations. As an example of an archetypical moral narrative about treasure hunting, we will concentrate on Steven Spielberg's first Indiana Jones movie Raiders of the Lost Ark (1981). Subsequently, to illustrate what is at stake in the teacher-student narrative, we will focus on the theme of the sorcerer's apprentice, which achieved global popular fame through Walt Disney's twentieth century animated cartoon version entitled The Sorcerer's Apprentice (1940). 


\section{Metagenomics as a practice of treasure hunting}

A typical example of an emerging field of research that endorses an ecotechnological perspective, is metagenomics, "the culture-independent genomic analysis of microbial communities" (Schloss and Handelsman 2003: 303). In the 1990s, most microbiologists still assumed that the majority of microorganisms in a sample could be recovered by culturing them in the laboratory. An increasing amount of evidence has nevertheless shown that "fewer than $0.1 \%$ of the microorganisms in soil are readily cultured using current techniques. [...] the other $99.9 \%$ of soil microflora is emerging as a world of stunning, novel genetic diversity" (Handelsman et al. 1998: 245). By enabling the culture-independent analysis of microbial populations, metagenomics has revolutionized the field of microbiology in two ways. Firstly, "it offers a window on an enormous and previously unknown world of microorganisms" (Handelsman 2007: 8). Knowledge of this world can help us solve various complex human problems:

"Metagenomics [...] promises to provide a more complete understanding of the global cycles that keep the biosphere in balance, offer clues to the basis for many diseases, lead to development of new antimicrobial therapies and present solutions to environmental and biotechnological challenges" (Idem: 8).

Secondly, metagenomics allows the study of microbial communities under nature's own conditions. Researchers in this field are aware of the fact that the artificial environments created in labs are very different from natural environments. In order to obtain a critical and realistic understanding of microbes in nature, they consider it essential to investigate microbial populations in their native habitats. Metagenomics can therefore be said to announce a new era in biology, "that of ecosystems biology" (Xu 2010: 1).

To draw attention to the wealth of products and applications yet to be discovered with the help of metagenomics, in various scientific publications and programmatic documents, this new practice of uncovering the Earth's microbial diversity is compared to a quest for a treasure. For instance, Brouwer argues that "unleashing these hidden treasures will create a huge potential for applications in the fields of sustainable chemistry, alternative energy, in biorefineries, and in bio-construction materials" (Brouwer 2008: 2). Moreover, the Committee on Metagenomics claims that the discovery of new genes and functions in soil "is one of the potential treasure troves of metagenomics" (Committee on Metagenomics 2007: 76; cf. Oh et al. 2003: 248; Park and Kim 2008: 163; Schoenfeld et al. 2010: 20). ${ }^{1}$

By presenting metagenomics as a quest for the valuable goods still hidden in nature, researchers in this field not only seek to explain their research activities, but also gain legitimacy and attract funding. This particular self-presentation gives the field an aura of adventure: it brings to mind the age of the great explorations. Most importantly, however, the treasure quest narrative reflects an investment that will require full commitment, yet with the promise of a great reward in the end. This reward should primarily be understood in material

\footnotetext{
${ }^{1}$ Even though metagenomics started as a method to study the collective genomes of the soil, the term nowadays covers the investigation of any microbial community: not only terrestrial and aquatic ecosystems, but also the human microbiome. The treasure quest narrative, however, is especially used to emphasize the wealth of natural ecological niches (e.g. soil, water, air).
} 
terms; the narrative self-presentation especially refers to products to be developed based on the as-yet-undiscovered goods that lie hidden in the soil (or other natural ecosystems), such as enzymes and antibiotics (Handelsman 2007). The confidence that the metagenomic quest is an effort worth making is also expressed by the amount of money invested in metagenomic research. Research projects at the J. Craig Venter Institute, for instance, are funded not only by government institutions (such as NSF and NIH), but receive great sums of money from family foundations as well. Thus, the prospect of new products beneficial to humans plays an important role in the justification of metagenomics, and is instrumental in helping to raise the required funding for what is yet a very open endeavor with a very uncertain outcome; metagenomics is one of the '-omics' research fields that "give rise to quite substantial promises and expectations for society", a promissory practice which has been referred to as promisomics (Chadwick and Zwart 2013: 1).

\section{Resourcism}

In the context of metagenomics, the ecotechnological turn is presented as a quest for the goods that nature has produced in the process of evolution. Nature appears as a superinnovator whose creations we can incorporate into our own technologies. There are, however, also more critical voices, claiming that the treasure quest narrative does not give a full picture of what is at stake in ecotechnology. Although this narrative underlines the superiority of nature's innovations, nature is still presented as a 'resource'. Resourcism has been the object of fundamental criticism by environmental thinkers for a long time. Philosopher Neil Evernden describes resourcism as "a kind of modern religion which casts all of creation into categories of utility" (1993: 23). It is based on the conviction "that nature is for something" (Idem: 10) and should therefore be protected. ${ }^{2}$ Resourcism was in itself a justified reaction against earlier forms of environmental advocacy, "preoccupied with aesthetics and metaphysics" (Idem: 4). It sought to replace the impractical and emotional testimonies of nature lovers like Henry David Thoreau and John Muir by rational arguments, underlining that wise management of natural resources is necessary to maintain current standards of living. Thus, "[w]here once only an anguished cry could be expected in defence of a threatened mountain or an endangered species, now a detailed inventory and a benefit-cost analysis [were] sure to be forthcoming" (Idem: 9).

According to Evernden, one of the typical features of resourcism is the strict separation between human and non-human nature. This feature is strongly represented by the American conservationist Gifford Pinchot (1865-1946), who believed that there were "just two things on this material earth - people and natural resources" (Pinchot 1947: 325). Evernden explains that this belief implies "the total dedication of the planet to human purposes - or rather to the contemporary human economy" (Evernden 1993: 150). Another result of separating the world in merely two realms - a human and a non-human realm - is that the complexity of the latter is severely underestimated. As Evernden argues: nature is treated "as homogeneous matter in search of a use" (Idem: 23). Val Plumwood, in a similar

\footnotetext{
${ }^{2}$ The resource approach to nature is also known under different names, for instance 'utilitarianism' and 'costbenefit analysis'. A popular present-day term expressing the idea that ecosystems are, above all, providers of goods and services, is 'ecosystem services'.
} 
vein, claims that this homogenization makes us insensitive to nature's marvellous diversity. The variety of nature is only taken into consideration if it is expected to contribute to human prosperity: "Nature is conceived in terms of interchangeable and replaceable units, (as 'resources', or standing reserve) rather than as infinitely diverse and always in excess of knowledge and classification" (Plumwood 2002: 107).

In Evernden's view, resourcism entails an even more dangerous aspect, namely "its apparent good intention. By describing something as a resource we seem to have cause to protect it. But all we really have is a license to exploit it" (Evernden 1993: 23 - our emphasis). The transformation of "all relationships to nature into a simple subject-object or user-used one" (Idem: 24) goes hand in hand with the devaluation of nature. Reducing a tree to a device that produces oxygen, argues Evernden, is debasing to being itself. In a similar fashion, describing microbial ecosystems as treasure troves reduces the world of microorganisms to "another material thing that can be utilized by humans" (Idem: 24). ${ }^{3}$

\section{Biomimicry as a tutorial practice}

The resource approach to nature is not only criticized by environmental thinkers, but increasingly also by scientists. In an attempt to give a less instrumental, less reductionist account of the stakes of ecotechnology, some of them have proposed alternative narratives that do more justice to nature's own creative processes. One of them is innovation consultant Janine Benyus. She argues that we should "view nature as a source of ideas instead of goods" (Biomimicry 3.8). In her influential book Biomimicry: Innovation Inspired by Nature (2002), Benyus describes how her vision on nature management changed. As a forestry student, she was taught a reductionist, human-centered approach to nature management. Each piece of the forest was studied separately:

"There were no labs in listening to the land or in emulating the ways in which natural communities grew and prospered. We practiced a human-centered approach to management, assuming that nature's way of managing had nothing of value to teach us" (Benyus 2002: 3).

When Benyus started her career as a science writer, she was impressed by the perfect ways in which organisms are adapted to their places and to each other. She wondered why human beings, while facing the same physical challenges as all our fellow species, tried to solve these challenges through human cleverness alone. Benyus decided to develop an alternative approach, in which organisms and natural systems are no longer regarded as resources available for unrestricted use, but as "the ultimate teachers" (Idem: 4 - our emphasis). Benyus gave this approach the name 'biomimicry', derived from the Greek bios ( $\beta 10 \varsigma)$, meaning life,

\footnotetext{
${ }^{3}$ The description of microbial systems as treasure troves is only one of the images expressing an exploitative attitude towards the natural world. Another image that can be found in metagenomics discourse is 'nature as a mine'. During an important inaugural meeting, the director of one of the most sizeable Dutch metagenomics centers gave a presentation in which he suggested the term 'nature mining' as a synonym for metagenomics research. Whereas part of the Dutch metagenomics community saw no harm in the commodification of nature that the term signifies, others had difficulties with the reduction of nature to a reservoir to be exploited (Van der Hout 2014).
} 
and mimesis ( $\mu \mu \eta \sigma \mathrm{\iota})$, to imitate. She describes biomimics as "men and women who are exploring nature's masterpieces [...] and then copying these designs and manufacturing processes to solve our own problems" (Idem: 2).

What is so revolutionary about this learning-from-nature movement? After all, there is a long and colorful history of engineers and scientists who gained inspiration from nature. A classic example is the Wright brothers, who succeeded in flying the first heavier-than-air airplane in 1903, taking inspiration from observations of turkey vultures in flight. Another well-known example is Joseph Paxton's Crystal Palace, which was built to house the Great Exhibition of 1851. Paxton's design of the Crystal Palace was inspired on the ribbed stem of a lily leaf (Ball 2001). In the 1950s, the American engineer Otto Schmitt turned these occasional applications of bio-inspired design into a more or less formal discipline. Instead of biomimicry, he proposed the term 'biomimetics' to describe the "transfer of ideas and analogues from biology to technology" (Vincent et al. 2006: 471). Benyus, however, appears to be (one of) the first to explicitly connect this discipline with "a new way of viewing and valuing nature" (Benyus 2002: front pages). She explains that biomimicry is much more than a particular approach to solving engineering problems:

"In a society accustomed to dominating or 'improving' nature, this respectful imitation is a radically new approach, a revolution really. Unlike the Industrial Revolution, the Biomimicry Revolution introduces an era based not on what we can extract from nature, but on what we can learn from her" (Idem: 2).

What does Benyus seek to express with her presentation of biomimicry as a tutorial practice? By introducing this alternative narrative, she distances herself from interpretations of the ecotechnological turn that - implicitly - support the conviction that "the world was put here exclusively for our use" (Idem: 8). To enable a more respectful approach to nature, it is not enough to recognize the excellent quality of the 'goods' produced by nature, nor will it suffice to see nature as a superior innovator; it requires that we start looking differently at ourselves as well. The recognition of nature as our mentor implies that we simultaneously recognize ourselves as nature's students, open to the lessons that nature has in store for us:

"Once we see nature as a mentor, our relationship with the living world changes. Gratitude tempers greed, and, [...] 'the notion of resources becomes obscene.' We realize that the only way to keep learning from nature is to safeguard naturalness, the wellspring of good ideas" (Idem: 9).

What kind of promise is contained in the presentation of biomimicry as a teacher-student relationship? How can this particular self-presentation legitimize the research activities of biomimics? Whereas the treasure quest narrative spoke of a material reward in the form of new products beneficial to humans, in the context of the teacher-student narrative the 'prize' is, above all, of an intellectual nature: if we listen carefully to nature's lessons, pay close attention to the ways in which our teacher tackles design challenges, we will ourselves become smarter and better problem-solvers as well. Benyus explains that nature has 3.8 billion years of design brilliance available for free: "After 3.8 billion years of research and 
development, failures are fossils, and what surrounds us is the secret to survival" (Idem: 3 ). Benyus's message did not fall on deaf ears: since the foundation of the Biomimicry Guild in 1998, she has inspired thousands of scientists, architects, designers, and innovators to use nature's models to create sustainable technologies, or, to put it differently, to become biomimics themselves.

\section{Stories small and large}

Benyus presents the tutorial narrative of biomimicry as being radically different from the treasure quest narrative used in the metagenomics field. But these two narrative selfpresentations are also strikingly alike in one respect: adherents of both sides have chosen these narratives because of the sympathetic models they provide. By connecting their research activities to these 'positive' stories, metagenomicists and biomimics seek to legitimize their scientific work. However, the two narrative self-presentations are embedded in larger, more common cultural narratives, to which they implicitly refer and which lend them their motivational force. This especially applies to the treasure quest narrative: by mentioning the word 'treasure', the audience immediately thinks of adventure and feels the excitement of discovery. However, even though ecotechnologists may more or less consciously refer to more general narrative structures, they do not take proper account of the ambivalence and multidimensionality of the broader treasure quest and teacher-student narratives. What is more, some of these broader stories are explicitly moral: they show us what is at stake in the practical situations we humans can find ourselves in.

When ecotechnologists ignore the inherent ambivalence of these broader moral narratives, they may find that their narrative self-presentations evoke unintended responses among audiences; the ambivalence that is repressed in a superficial and straightforward use of the narrative will re-emerge in the way in which the message is perceived and appreciated by others. What is intended to be an unambiguous story about our effort to do something univocally 'good' can unwillingly evoke moral sentiments of a much more complicated nature. In the next sections, we will show the ambivalence of both the treasure quest and teacher-student narratives, using the movies Raiders of the Lost Ark (1981) and The Sorcerer's Apprentice (1940) as illustrations.

\section{Raiders of the Lost Ark}

Treasure hunting is a classical theme in literature, art and film. As explained in the above section, most stories dealing with this theme are surprisingly multi-layered and ambivalent. Typically, they show sympathy for those who yield to the temptations of treasure hunting, but also contain a lesson about the risks of giving in to this temptation. In many treasure quest stories, we meet two types of hunters: one most of us sympathize with - a character who seeks the treasure mainly to satisfy his (or, less frequently, her) intellectual curiosity, but nevertheless shows not to be immune for its material value; and another who seeks the treasure for his profit alone, whose greed has turned him into a villain. Usually, the latter comes to a bad end in the dramatic closing scene, whereas the former has gained a new perspective on the trivial meaning of the search for personal gain.

One of the best-known contemporary treasure hunter tales is that of Indiana Jones. Here, we want to concentrate on the first part of the Jones series: Raiders of the Lost Ark 
(1981). ${ }^{4}$ The film, directed by Steven Spielberg and produced by George Lucas, tells the story of the archaeologist Indiana ('Indy') Jones. Indy, played by Harrison Ford, is hired by the American government to prevent the Nazis from getting hold of the Ark of the Covenant, which is believed to still hold the Ten Commandments. The anti-Semitic Nazis seek to turn this Jewish artefact into a weapon of world conquest and domination. The Ark is said to hold immense mystical power: "The Bible tells of it levelling mountains and wasting entire regions. Moses promised that when the Ark was with you, your enemies will be scattered and your foes fell before you. [...] An army which carries the Ark before it is invincible" (Raiders of the Lost Ark).

Right from the start of the movie, the spectator has no difficulties in being sympathetic to Indy. Why do we consider him a hero, in spite of the fact that some of his actions are morally dubious? The main reason appears to be that Indy does not fit to the picture of an ordinary plunderer, who is blinded by greed. More than a raider, Indy is an archaeologist who seeks to fulfil his intellectual curiosity. He is searching for rare and ancient artefacts because of their cultural and historical significance. Moreover, Indy does not keep the treasures for himself: they will be stored in a museum, accessible to the public.

Indy's heroism becomes even more pronounced in contrast with his French nemesis René Belloq. Despite being an archaeologist like Indy, Belloq is driven by the quest for personal glory and power only. His immorality is underlined by his willingness to collaborate with the Nazis. Throughout the film, Belloq is trying to convince Indy that the two of them are one of a kind. Belloq's first attempt occurs when he meets a depressed and drunken Indy. The latter assumes that his (former) lover Marion has died in an explosion. It is then that Belloq tells him:

"You and I are very much alike. Archaeology is our religion, yet we have both fallen from the purer faith. Our methods have not differed as much as you pretend. I am a shadowy reflection of you. It would take only a nudge to make you like me, to push you out of the light" (Raiders of the Lost Ark).

As spectators, we can see the doubt in Indy's eyes: he almost seems to believe that Belloq is right. Not only Indy, but also the spectator is invited to ponder the extent to which Belloq's reflections are correct. Indy is very eager to find the Ark before Belloq and the Nazis do, not only to prevent them from becoming inconquerable, but also to keep up his reputation; the quest for the Ark is also a competition between two prominent archaeologists, having their own professional pride, and defending their countries' honor.

The question concerning the likeness between Belloq and Indy keeps coming back almost until the end of the movie. Belloq, who has stolen the Ark from Indy, tells the Nazis that he wants to test its power before presenting it to Hitler (whereas in fact, he wants to keep the Ark for himself). When they arrive on a desert island, Indy reveals himself and threatens

\footnotetext{
${ }^{4}$ Examples of other movies in this genre are Treasure Island (e.g. 1950 and 1990), based on the novel by Robert Louis Stevenson (1883); King Solomon's Mines (for instance 1937 and 1950), based on the novel by Henry Rider Haggard (1885); Mutiny on the Bounty (for instance 1935 and 1962); The Mummy (1999, 2001, and 2008); National Treasure (2004 and 2007); The Librarian (2004, 2006, and 2008).
} 
to destroy the Ark with a bazooka. Belloq, however, realizes that Indy wants to know what the Ark contains as much as anyone:

"Yes, blow it up! Blow it back to God. All your life has been spent in pursuit of archaeological relics. Inside the Ark are treasures beyond your wildest aspirations. You want to see it open as well as I. Indiana, we are simply passing through history. This... this is history. Do as you will" (Raiders of the Lost Ark).

While Belloq performs a ceremonial opening of the Ark, Indy and Marion are fastened to a post. At first, the Ark appears to contain nothing but sand dust, the remains of the stone tablets. Suddenly, however, spirits emerge from the Ark. It is at this exact moment that the crucial difference between Belloq and Indy becomes clear: aware of the supernatural danger of looking at the unveiled Ark, Indy warns Marion to close her eyes: "Marion, don't look at it. Shut your eyes, Marion. Don't look at it, no matter what happens!" (Raiders of the Lost Ark). Meanwhile, the spirits change into angels of death; Belloq and all the Nazi soldiers die terrible deaths.

\section{Contextualized criticism}

The scene in which Indy warns Marion to close her eyes is the film's pivotal moment. Indy starts his quest for the Ark with noble intentions. But in the process of getting closer to it, he yields to the temptation of making it his own. Face to face with the Ark's mystical powers, Indy realizes - and we as his spectators with him - that power and greed almost blinded him: he now understands that not the Ark, but the wisdom obtained during the expedition, is the most important prize. Belloq's refusal to learn this lesson leads to his gruesome end. By featuring two types of treasure hunters, the narrative structure of the movie reminds the audience that treasure hunting has its moral challenges, and that we are at risk of losing our souls if we allow ourselves to be blinded by greed.

In the second Jones-film, Indiana Jones and the Temple of Doom (1984) - which, apart from the end, has a rather thin storyline - this moral message is expressed even more clearly. The inhabitants of a small Indian village ask Indy to retrieve a sacred rock that has been stolen from them by the followers of an evil cult. Having survived an incredible number of deadly traps, Indy hands over the rock to the village leader. Night-club singer Willie, who earlier in the film was shown to have a weakness for diamonds, notes that he could have kept the rock, on which Indy answers her: "What for? They'd just put it in the museum, it'd be another rock collecting dust." Willie counters him by saying: "But then it would have given you your fortune and glory." However, Indy realizes that the value of his quest lies in the lessons learned, not in possessing the sacred rock. He tells the village leader that he "understand[s] its power now" (Indiana Jones and the Temple of Doom).

What lessons could metagenomic researchers learn from Raiders of the Lost Ark? What is the film's surplus value compared to the criticism on resourcism expressed by Evernden and Plumwood? Raiders reveals a strikingly subtle stance towards treasure hunting. The main reason for this appears to be that the criticism is an inherent dimension within the story: it is not an external comment or afterthought, but a dimension that unfolds as the story progresses. By introducing Indy and Belloq as two opposites (who nonetheless seem to show 
at least some resemblances), the film pictures treasure hunting as a practice that is not by definition 'good' or 'bad'. Raiders is sympathetic to the temptations of treasure hunting, yet at the same time confronts us with one of its inherent dangers, namely that the promise of possessing the 'prize' may become an obsession, obscuring any insight. It shows us that, in the process of getting closer to the treasure, we run the risk of losing our soul. By contrast, the philosopher's criticism on resourcism remains to a large extent external. If we express Evernden's and Plumwood's criticism in terms of treasure hunting, they seem to focus on one form of treasure hunting only, namely the greedy, Belloqian variant. As the criticism expressed in Raiders of the Lost Ark is much more subtle, it seems more capable of showing metagenomic researchers what is at stake: we ourselves are at stake if we become obsessed by the material reward awaiting us.

By looking at the broader cultural narrative of treasure hunting, we learn that knowledge about the moral risks inherent to this practice is at least implicitly present in the popular cultural domain. Of course we could have referred to more 'highbrow' forms of art and literature. But what the Indiana Jones example shows us, is that even a Hollywood blockbuster narrative on treasure hunting is much more ambivalent than the univocal selfpresenting narrative of metagenomicists. It should therefore not come as a surprise that their self-presentation is not unanimously applauded but rather meets with skepticism and moral reservation. It is not enough to know that the metagenomic quest for the goods of nature contains the promise of a treasure; we also need to be assured that this quest is not blinded by greed. For as 'we' all know, not much good can come from that.

\section{The Sorcerer's Apprentice ${ }^{5}$}

What about the alternative narrative of ecotechnology? As we showed earlier, Benyus seeks to provide a different perspective on the implications of the ecotechnological turn. It does not suffice that we recognize the superiority of nature's goods; we have to become nature's humble students, showing respect for nature's superior wisdom. But here, again, the selfpresentation relies on a larger, more widely shared moral narrative about what it means to be a pupil, and about what can go wrong.

A classic tale resonating in Benyus's presentation of biomimicry as a tutorial practice is The Sorcerer's Apprentice. ${ }^{6}$ The tale knows many versions. Its original dates from the second century $\mathrm{AD}$, and is attributed to the satirist and rhetorician Lucian of Samosata. Probably today's most well-known version is Walt Disney's ten-minute animated version of The Sorcerer's Apprentice, which is the third segment of the film Fantasia (1940). This particular version is based on Paul Dukas's symphonic interpretation L'apprenti sorcier (1897) of Goethe's poem Der Zauberlehrling (1797). The popularity of the Disney version is shown by the fact that in Fantasia 2000, the sequel to the 1940 film, the segment about the apprentice Mickey Mouse is the only one retained. Following the story from Goethe's poem closely, Disney introduced the tale to a worldwide audience. The dialogue-free cartoon is

\footnotetext{
${ }^{5}$ An edited version of the next 2 sections has been adopted in a chapter of the volume Animal Ethics in the Age of Humans. Blurring boundaries of human-animal relationships (eds. Bovenkerk \& Keulartz, 2016).

${ }^{6}$ In describing the learning process that turned her into a real biomimic, Benyus compares herself to the Sorcerer's Apprentice: “... but like the Sorcerer's apprentice, I managed only to create more duckweed” (2002, 286).
} 
introduced by a narrator, who gives a description of the apprentice, a role played by Mickey Mouse:

"He was a bright young lad; very anxious to learn the business. As a matter of fact, he was a little bit too bright, because he started practicing some of the boss's best magic tricks before learning how to control them" (Fantasia).

At the beginning of the cartoon, we meet the wise and powerful sorcerer Yen Sid (Disney in reverse), who is working on his magic. His pupil Mickey is fetching water to fill a large tub. When the sorcerer leaves to his chambers, Mickey puts on Yen Sid's hat and sits down to look through his master's magic spell book. Tired of carrying the buckets, he uses the sorcerer's magic to bring a broom to life and make it fetch water for him. Mickey is proud not to be a pupil for once, but to equal his master instead. He falls asleep and dreams that he is a powerful sorcerer standing on a mountaintop, commanding the stars, planets and sea.

Mickey, however, cannot sleep for very long: he suddenly jolts awake to find the room filled with water. The tub is overflowing, as the broom continues carrying water to it. Mickey orders the broom to stop, but his wooden servant does not listen to him. Grabbing an axe, Mickey chops the broom into pieces. Just when things seem to have calmed down, Mickey's attempt to break the spell turns against him: the small pieces of the broom begin to move and each of them transforms into a whole new broom. Soon, an entire army of brooms fills the overflowing tub with even more water. Mickey turns over the leaves of his master's book, hoping to find the right spell to stop the brooms. Just as Mickey is about to drown, a stern and angry Yen Sid appears. With a wave of his hands, the water descends. Mickey, feeling very guilty, takes off the sorcerer's hat and returns it to its master. Then he picks up the buckets to finish his chores.

\section{Hubris}

The tale of The Sorcerer's Apprentice shows us in a light-hearted manner how dangerous it can be to overestimate oneself. Mickey Mouse's hubris appears to be twofold: he is unaware of his incompetence and assumes that he already fully grasps and controls Yen Sid's powers. Having succeeded in enchanting the broom, this assumption is initially confirmed. Only after things have got out of hand, he realizes that he is not yet ready to imitate his master. Yet, Mickey's attempt to use Yen Sid's magic for his own good also reflects a more fundamental hubris. The apprentice does not seem to know the difference between tricks and magic; he mistakenly assumes that magic is only about tricks. Mickey is not aware that there are things that cannot be learned by reading textbooks or diligent practice. This second form of selfoverestimation also brings to light another important difference between Mickey and the sorcerer. The latter is not only smart, but also wise: he knows how to separate essentials from peripheral issues. Mickey, by contrast, does not (yet) fully recognize the insignificance of some of his goals. Unable to see the bigger picture, he uses Yen Sid's magic powers for something as trivial as filling a tub with water. If Mickey would have used his master's powers for more serious purposes - saving Minnie Mouse, for instance - the latter probably would not have gotten that angry. Yen Sid seems especially irritated by the fact that Mickey's 
decision to use the sorcerer's spells is motivated by laziness, and does not serve any serious goal. $^{7}$

What could Benyus and other biomimics learn from Mickey Mouse? The tale of The Sorcerer's Apprentice reveals that the knowledge gained during nature's lessons can bring us into trouble, especially if we do not acknowledge that our understanding is only fragmentary and finite. Even in the process of getting smarter and more resourceful, we have to bear in mind that we are still students, and, in a certain way, will always remain so. Moreover, the tale encourages biomimicry practitioners to reflect on the question whether they keep their eyes on the bigger picture, for instance when they compare nature to "a superior $R \& D$ department" ${ }^{\prime 8}$. We just explained that Mickey, being able to perform (at least some) spells, still needs to learn to choose his objectives carefully. In a similar fashion, biomimics should not fail to look critically at the goals to which they apply nature's lessons. They have to keep asking the question: "Why do we want what we want?" Comparing nature to a research and development department involves a projection of what we consider to be important. ${ }^{9}$ The realization that the idea of nature as a 'problem solving machine' is a human projection and misappropriation, could help distinguish between serious demands for new technologies and the more trivial motives that are also at play in current technology development.

The above shows that, although Benyus opposes the tutorial narrative to presentations in which nature appears as a source of 'goods', her narrative self-presentation has its own ambiguity. In the end, the 'bad' student who uses his teacher's lessons merely to empower himself is not that different from the greedy treasure hunter who seeks the treasure for his or her own profit alone. Thus, the proposal to view nature as a source of 'ideas' rather than 'goods' does not protect Benyus from the dangers inherent to the latter narrative selfpresentation: not only nature's goods, but also her wisdom or creativity can be used in a reductionist and instrumental fashion.

\section{Conclusion}

Science needs narrative structures, metaphors, and images to explain and legitimize research practices that are usually described in an abstract and technical manner in academic publications and programmatic documents. Yet, in their narrative self-presentations, scientists tend to underestimate the complexity and multi-layered character of these 'master-narratives', notably in terms of the moral message contained in them. This also applies to the two narratives of ecotechnology that were analyzed in this article. The strategic use of these narratives by ecotechnologists for expectation management tends to overemphasize the

\footnotetext{
${ }^{7}$ Unlike Yen Sid, Goethe's sorcerer is not angry with his apprentice for having tried to equal his master. He tells off the broom for having followed the orders of someone other than his old master: "Back now, broom,/into the closet! /Be thou as thou/wert before!/Until I, the real master/call thee forth to serve once more!" (translated by Brigitte Dubiel [http://german.about.com/library/blgzauberl.htm] - accessed 11 March 2016).

${ }^{8}$ Bas Sanders. 31 October 2013. "Biomimicry - Leren van de natuur?" Symposium on "The Essence of Sustainability", Hortus Arcadië, Radboud University Nijmegen. Benyus also describes nature in terms of R\&D: "After 3.8 billion years of research and development, failures are fossils, and what surrounds us is the secret to survival" (2002: 3).

${ }^{9}$ In his well-known criticism of ecological restoration, Eric Katz has a similar argument when he criticizes the implicit assumption of many ecological restorationists that nature has a blue print that we try to mimic: "But Nature, of course, does not have a blueprint, nor a design" (Katz 2000: 87).
} 
positive potential for society and nature of the research fields in question, and underestimate the moral ambivalence of the larger master-narratives that they build upon. Yet, as we have shown, even popular cinematic versions of these master-narratives reveal a widely shared awareness of the moral ambivalence of the issues at stake. And this applies both to the treasure quest and the tutorial narratives. This means that genres of the imagination (novels, fairy tales, poems, but also movies) can be used as a window into the ambivalences and ambiguities of the narratives employed. Rather than refraining from using narrative selfpresentations, we argue that, whenever scientists use them, this richness must be more explicitly addressed. We believe that a self-presentation of ecotechnology in narrative terms can indeed help understand the moral stakes of technological innovations. However, when scientists merely tap into these broader master-narratives without acknowledging their inherent ambivalence, the communication strategy that aims at public expectation management could very well backfire.

\section{Acknowledgements}

This study was conducted under auspices of the CSG Centre for Society and the Life Sciences, a Centre of Excellence funded by the Netherlands Genomics Initiative. We would like to convey our special thanks to Hub Zwart and two anonymous referees for valuable comments that helped improve this text.

\section{References}

Algar, James (dir.). 1940. Fantasia. Burbank, CA: Walt Disney Productions.

Ball, Philip. 2001. 'Life's lessons in design.” Nature 409: 413-416.

Bensaude-Vincent, Bernadette, Hervé Arribart, Yves Bouligand, and Clément Sanchez. 2002.

"Chemists and the school of nature." New Journal of Chemistry 1: 1-5.

Benyus, Janine M. 2002. Biomimicry: Innovation inspired by Nature. New York: Harper

Perennial.

Biomimicry 3.8. 2014. "Conversation with Janine.” http://biomimicry.net/about/ biomimicry/conversation-with-janine/ (accessed 11 March 2016).

Borup, Mads, Nik Brown, Kornelia Konrad, and Harro van Lente. 2006. "The sociology of expectations in science and technology." Technology analysis and strategic management 18 (3/4): 285-298.

Brouwer, Bram. 2008. "Sustainable Development of Bio-Based Applications in Chemical Industry." Grant proposal of the Ecogenomics Innovation Centre (ECOLINC).

Chadwick, Ruth, and Hub Zwart. 2013. "From ELSA to responsible research and Promisomics." Life Sciences, Society and Policy 9 (3): 1-3.

Committee on Metagenomics: Challenges and Functional Applications, National Research Council. 2007. The New Science of Metagenomics: Revealing the Secrets of our Microbial Planet. Washington, DC: National Academies Press.

Dupuy, Jean-Pierre. 2010. "The Narratology of Lay Ethics.” Nanoethics 4 (2): 153-170.

Evernden, Neil. 1993. The Natural Alien. Humankind and Environment. 2nd ed. Toronto: University of Toronto Press.

Handelsman, Jo. 2007. "Metagenomics and Microbial Communities." Encyclopedia of Life Sciences, 10.1002/9780470015902.a0020367. 
Heller, Agnes. 2006. "European master-narratives about freedom" in Handbook of European social theory, ed. Gerad Delanty, pp. 257-265. London: Routledge.

J. Craig Venter Institute. 2006. "Global Ocean Sampling Expedition.” http://www. jcvi.org/cms/research/projects/gos/overview/ (accessed 11 March 2016).

Kasdan, Lawrence, and George Lucas. 1979. Raiders of the Lost Ark. Screenplay, revised third draft. Medway Productions, Inc.

Katz, Eric. 2000. "The Big Lie: The Human Restoration of Nature” in Environmental Restoration: Ethics, Theory, and Practice, ed. William Throop, pp. 83-93. New York: Prometheus Books.

McDonough, William, and Michael Braungart. 2002. Cradle to Cradle: Remaking the Way We Make Things. New York: North Point Press.

Oh, Hyo-Jeong, Kyoung-Won Cho, In-Su Jung, Won-Ho Kim, Byung-Ki Hur, and GeunJoong Kim. 2003. "Expanding functional spaces of enzymes by utilizing whole genome treasure for library construction." Journal of Molecular Catalysis B: Enzymatic 26: 241-250.

Park, So-Youn, and Geun-Joong Kim. 2008. "A biological treasure metagenome: Pave a way for big science.” Indian Journal of Microbiology 48 (2): 163-172.

Pinchot, Gifford. 1998. Breaking New Ground. New York: Island Press.

Plumwood, Val. 2002. Environmental Culture: the Ecological Crisis of Reason. New York: Routledge.

Schloss, Patrick, and Jo Handelsman. 2003. "Biotechnological prospects from metagenomics." Current Opinion in Biotechnology 14 (3): 303-310.

Schoenfeld, Thomas, Mark Liles, K. Eric Wommack, Shawn W. Polson, Ronald Godiska, and David Mead. 2010. "Functional viral metagenomics and the next generation of molecular tools." Trends in Microbiology 18 (1): 20-29.

Sloterdijk, Peter, and Hans-Jürgen Heinrichs. 2006. Die Sonne und der Tod. Dialogische Untersuchungen. Frankfurt am Main: Suhrkamp.

Spielberg, Steven (dir.). 1981. Raiders of the Lost Ark. Hollywood, CA: Paramount Pictures. Spielberg, Steven (dir.). 1984. Indiana Jones and the Temple of Doom. Hollywood, CA: Paramount Pictures. Van der Hout, Sanne. 2013. "Bridging the lab-field divide? The 'eco' in ecological genomics." History and Philosophy of the Life Sciences 35 (4): 577598.

Van der Hout, Sanne. 2014. "Nature is (a) mine: Conceptions of nature in the Dutch ecogenomics community." Life Sciences, Society and Policy 10 (10): 1-16.

Van der Hout, Sanne. 2016. "Organisms as teachers? The promise of biomimicry" in Animal ethics in the Age of Humans. Blurring Boundaries of human-animal relationships, eds. Bernice Bovenkerk and Jozef Keulartz, p. 39-51. Dordrecht: Springer.

Vincent, Julian F.V., Olga A. Bogatyreva, Nikolaj Bogatyrev, Adrian Bowyer, and AnjaKarina Pahl. 2006. "Biomimetics: its practice and theory." Journal of the Royal Society Interface 3: 471-482.

Xu, Jianping. 2010. "Metagenomics and Ecosystems Biology: Conceptual Frameworks, Tools and Methods" in Metagenomics: Theory, Methods and Applications, ed. Diana Marco, pp. 1-13. Norfolk, UK: Caister Academic Press. 